\title{
Access to competition authorities' files in private antitrust litigation
}

\author{
Sebastian Peyer ${ }^{*}$
}

\begin{abstract}
The growth of private antitrust litigation in the courts of the Member States creates tensions between claimants and competition authorities. Claimants seek access to confidential records held by the authorities while the competition authorities try to maintain the confidentiality of those files. This paper analyses the two main access routes to confidential information in the files of competition authorities in the EU. It first looks at access under Regulation 1049/2001 (Transparency Regulation). Then, the paper assesses the framework for disclosure in the national courts, analysing the Court of Justice's Pfleiderer and Donau Chemie decisions, its application in England and Germany, and the changes that are required with the adoption of the Damages Directive. This author finds that both access routes tend to favour the protection of authority files and that accessseeking parties face high legal thresholds for the disclosure of files and leniency documents. I will argue that the raised standard for access demonstrates a policy change regarding private antitrust enforcement. EU policy makers and the courts have begun to moderate the principle of effective redress as expressed in Courage and Manfredi. In order to minimise repercussions for public enforcement they reduce the incentives for claimants to bring follow-on damages actions.
\end{abstract}

Key words: Competition law; Private antitrust enforcement; Damages Directive; damages actions; access to information; disclosure

JEL Code: K21, K40, K41

\footnotetext{
* Lecturer in Law at the University of Leicester, email: sebastian.peyer@le.ac.uk. I would like to thank the participants of the $9^{\text {th }}$ ASCOLA Conference 2014 and two anonymous referees for their helpful comments. I also gratefully acknowledge the support of the ABA Section of Antitrust Law Scholar in Residence Programme.
} 


\section{Introduction}

Access to information is crucial for the enforcement of the competition rules. Both competition authorities and private claimants depend on information about markets and firms' conduct to prove a violation of Articles 101 or 102 TFEU. Potential claimants are particularly interested in information from the competition authorities as the latter possesses superior means of gathering incriminating evidence. However, competition authorities are rather protective of their files and object to the disclosure of confidential information which they have obtained through dawn raids, leniency programmes or settlement procedures.

The competition authorities promise the confidentiality of voluntarily submitted information to encourage firms to come forward with incriminating material or settle investigations. ${ }^{1}$ The European Commission insists that the disclosure of information received from firms under investigation would potentially increase the cooperating firm's exposure to civil liability and offset the incentives created by the leniency programmes or settlement procedures. Consequently, companies would be discouraged from sharing crucial information with the law enforcers. Victims of anticompetitive conduct seek to enforce their right to compensation, and to do so require access to information. Although the finding of a competition infringement has probative value in many Member States and facilitates the bringing of follow-on claims, ${ }^{2}$ information about overcharges and markets are required to proof damages and causation. ${ }^{3}$ The ease with which information can be accessed in the Member States also determines the jurisdiction that is best suited to bring a case against a multi-national defendant. ${ }^{4}$ The claimant's interest in disclosure normally clashes with the competition authority's interest in the protection of files. The conflict of interests comes to the fore when the private claim is commenced at a time when the public investigation is ongoing or after the public investigation has been closed (follow-on case), and the European Commission or national competition authority is being asked to reveal documents that are confidential or were crucial for the investigation concerned.

The conflicting interests regarding access to documents have prompted the courts to rule on access requests on a number of occasions. Two types of access requests have been particularly prominent. ${ }^{5}$

\footnotetext{
${ }^{1}$ Commission Notice on Immunity from fines and reduction of fines in cartel cases, [2006] OJ C 298-17, para 40. Joaquín Almunia, Antitrust damages in EU law and policy (Speech College of Europe GCLC annual conference, 07/11/2013), SPEECH/13/887.

${ }^{2}$ Many Member States have already an established legal practice or statutory provisions that facilitate the proof of infringement in follow-on cases: Cyprus, Czech Republic, Germany, Greece, Hungary, Ireland, Malta, Slovenia, Spain and the UK. Based on Barry J Rodger, Competition Law: Comparative Private Enforcement and Collective Redress across the EU (Kluwer Law International, Alphen aan den Rijn 2014) 34-41.

${ }^{3}$ Article 9 of the Directive of the European Parliament and of the Council on certain rules governing actions for damages under national law for infringements of the competition law provisions of the Member States and of the European Union (Damages Directive) makes the final decision of a national competition authority effectively binding in national courts.

${ }^{4}$ For the choice of jurisdiction in the EU see Council Regulation (EC) No 44/2001 of 22 December on jurisdiction and the recognition and enforcement of judgements in civil and commercial matters [2001] OJ L12.

${ }^{5}$ For other potential access routes see Gianni de Stefano, "Access of Damage Claimants to Evidence Arising out of EU Cartel Investigations: a Fast Evolving Scenario" (2012) 5(3) Global Competition Litigation Review 95-110. He discusses access to published decisions of the competition authorities, the potential access to documents for complainants in investigations, disclosure in non-EU courts and the option of becoming an intervener in appeal proceedings before the Court of Justice. These routes do not include direct access to confidential
} 
Potential claimants have sought direct access to the European Commission's files using the Transparency Regulation or applied for inter partes disclosure in the national courts. ${ }^{6}$ The Court of Justice of the European Union (CEJU) has dealt with both access paths in recent decisions and has developed standards for accessing information that is in the hands of the competition authorities. ${ }^{7}$

In this article, I will scrutinise and compare the two direct routes for claimants to access documents that are or were in the hands of the European Commission or national competition authorities. In particular, I will look at the legal tests for access according to the Transparency Regulation and the EU framework that has been established for disclosure in the national courts. For both tests the questions arises if and how documents can be accessed and what level of protection is afforded to documents that stem from cooperating firms. I will also look at the changes regarding disclosure that are brought about by the Damages Directive that has recently been approved by the European Parliament and the Council. ${ }^{8}$

My analysis demonstrates that the private antitrust enforcement policy has changed. The courts and the European Commission seem to discourage follow-on actions, i.e. claims that rely on public investigations, and provide more incentives for victims of anticompetitive conduct to bring standalone claims. The first EU policy papers relating to private actions as well as the Courage and Manfredi judgements of the CJEU fully embraced a right to compensation for any individual affected by a breach of competition law. ${ }^{9}$ The European Commission favoured a strengthened regime of private actions, explicitly including follow-on litigation. ${ }^{10}$ It suggested a number of measures that would provide more incentives for victims of anticompetitive conduct to bring antitrust cases in the courts of the Member States. The recent case law of the Court of Justice and the Damages Directive promote are more nuanced approach. Both the Court and the Commission recognise the conflicting interests of private parties and competition authorities as well as the competing objectives of public and private enforcement, especially with regards to follow-on actions. ${ }^{11}$ This is evidenced by a shift

information in the EU courts but, instead, rely on the claimant's status as a complainant or intervener (indirect access) or they use non-EU courts. Potentially, an alternative route to access is available through Article 15(1) of Regulation 1/2003: "In proceedings for the application of Article 81 or Article 82 of the Treaty, courts of the Member States may ask the Commission to transmit to them information in its possession or its opinion on questions concerning the application of the Community competition rules." However, this is not a direct route to gain access to information and it will not be discussed in this article.

${ }^{6}$ Regulation 1049/2001 of the European Parliament and of the Council of 30 May 2001 Regarding Public Access to European Parliament, Council and Commission Documents, [2001] OJ L /145- 43 (hereinafter Transparency Regulation).

${ }^{7}$ Transparency Regulation: C-365/12 P EnBW Energie Baden-Württemberg AG v European Commission; for other cases under the Transparency Regulation see T-437/08 Hydrogene Peroxide Cartel Damage Claims v European Commission (CDC Hydrogene Peroxide) [2011] ECR II-08251; T-344/08 EnBW Energie BadenWürttemberg AG v European Commission; T-380/08 Netherlands v European Commission. Access through national procedure: C-360/09 Pfleiderer AG v Bundeskartellamt [2011] ECR I-05161; C-536/11 Bundeswettbewerbsbehörde v Donau Chemie AG [2013].

${ }^{8}$ The European Parliament adopted the proposal on 17 April 2014 and the EU Council of Ministers on 10 November 2014.

${ }^{9}$ C-453/99 Courage Limited v Bernard Crehan, [2001] ECR I-06297; C-295/04 Manfredi v Lloyd Adriatico Assicurazioni SpA [2006] ECR I-6619.

${ }^{10}$ European Commission, 'Green Paper - Damages Actions for Breach of the EC Antitrust Rules' (Brussels 2005); European Commission, "White Paper on Damages Actions for Breach of the EC Antitrust Rules" (Brussels 2008). The objective of strengthening follow-on actions was explicitly included in the Green Paper at para 1.3. ${ }^{11}$ See recital 6 of the Damages Directive. 
towards stricter requirements for access to information held by the competition authority, mainly affecting follow-on damages litigation. ${ }^{12}$

The remainder of the paper is structured as follows: The next part II assesses access to files under the Transparency Regulation. Part III looks at the legal test for protection of information under national procedure (Pfleiderer and Donau Chemie), the reception of this test in the courts of Germany as well as England and Wales, and the Damages Directive. Section IV documents the policy change and its implications for EU private antitrust policy. Section $V$ concludes.

\section{Access to Commission documents under the Transparency Regulation}

This section outlines the legal test for third-party access to information in cartel proceedings under the Transparency Regulation. Over the past decade the CJEU has developed a test under Article 4 of that Regulation that was recently applied to cartel-related access requests in EnBW. This section demonstrates that the approach favoured by the CJEU has created a high threshold for access to cartel-related information and that the current interpretation of the Article 4 exemptions is likely to block disclosure requests in competition proceedings, thus creating barriers for follow-on claims.

\section{Developing a legal test for access to cartel-related documents}

The Transparency Regulation grants individuals the right to access public documents held by EU institutions. Public access to (competition) authority documents shall enable citizens to participate more closely in the decision-making process and increase the accountability of the administration: ${ }^{13}$ "The purpose of this Regulation is to give the fullest possible effect to the right of public access to documents and to lay down the general principles and limits on such access in accordance with Article 255(2) of the EC Treaty." ${ }^{14}$ In competition law proceedings access-seeking parties are less likely to request information from the European Commission to hold the administration accountable but are more likely to pursue their interests in compensation. It is said that these privately motivated requests have fewer social benefits. ${ }^{15}$ However, even privately motivated access requests still serve the purpose of making public procedure more transparent and increasing transparency. Furthermore, individuals have the right to compensation for breaches of EU competition law. ${ }^{16}$ The right to compensation is flanked by the principle of effectiveness that requires Member States not to render the exercise of the right to compensation impossible or excessively difficult. The same

\footnotetext{
${ }^{12} \mathrm{EnBW}(\mathrm{n} 7)$. Articles 6 and 7 Damages Directive.

${ }^{13}$ See recital 2 and 4 of the Transparency Regulation.

${ }^{14}$ Recital 4 of the Transparency Regulation. Article 255(2) of the EC Treaty has become Article 15(3) TFEU with the Treaty of Lisbon.

${ }^{15}$ Dariusz Adamski, "Access to Documents, Accountability and the Rule of Law-Do Private Watchdogs Matter?" (2014) 20(4) European Law Journal 520, 534.

${ }^{16}$ Courage (n 9); Manfredi (n 9).
} 
principle must also apply to EU institutions if their assistance is needed to enforce the EU right for damages in the courts of the Member States.

The right to public access can be restricted where a prevailing public or private interest demands confidentiality according to Article 4 of the Transparency Regulation. ${ }^{17}$ The CJEU has repeatedly stressed that any restriction of the right to access must be read narrowly. ${ }^{18}$ Institutions can refuse access to documents when the disclosure would undermine the protection of privacy and the integrity of the individual (Article 4(1)(b)), when disclosure would undermine the protection of commercial interests, court proceedings and legal advice, or disclosure would compromise the purpose of inspections and investigations unless there is an overriding public interest in disclosure (Article 4(2)). ${ }^{19}$ Access to documents shall also be denied when the disclosure of documents drawn up for internal use or received by an institution would seriously undermine the institutions decisionmaking process (Article 4(3)). With regards to competition law investigations, the European Commission has argued that the disclosure of files to third parties would undermine the purpose of the investigation (third indent of Article 4(2)), the protection of the commercial interests of the undertakings concerned (first indent of Article 4(2)), the institution's internal decision-making process (Article 4(3)), and the protection of legal advice (second indent of Article 4(2)). ${ }^{20}$

The CJEU first outlined the test for access to information in relation to state aid and merger proceedings. ${ }^{21}$ In these early proceedings the CJEU and the General Court (GC) developed different views on the appropriate test for access to information. In Technische Glaswerke Ilmenau the Commission had refused to grant access to documents relating to the review of state aid. ${ }^{22}$ The CJEU confirmed the Commission's decision. According to the specific rules governing state aid investigations, firms will not be able to obtain access to files and documents. ${ }^{23}$ If firms were granted access to documents under the Transparency Regulation, this would potentially undermine the state aid review procedure. The CJEU created a rebuttable presumption in favour of the European

\footnotetext{
${ }^{17}$ C-266/05 P Sison v Council [2007] ECR I-1233, para 62; C-139/07 P Commission v Technische Glaswerke IImenau [2010] ECR I-5885, para 53 and joined cases C-514/07 P, C-528/07 P, C-532/07 P, Kingdom of Sweden v Association de la presse internationale ASBL (API) and European Commission, [2010] ECR I-08533, para 70.

${ }^{18}$ For access requests preceding the Transparency Regulation see C-174/98 P and C-189/98 P, Netherlands and van der Wal v Commission of the European Communities [2000] ECR I-1, para 27; T-211/00, Kuijer v Council of the European Union [2002] E.C.R. II-485, para 55. For the Transparency Regulation see cases C-64/05 P Sweden v Commission [2007] ECR I-11389, para 66; joined cases C-39/05 P and C-52/05 P, Kingdom of Sweden and Maurizio Turco v Council of the European Union, [2008] ECR I-04723, para 36; CDC (n 7) para 36.

${ }^{19}$ For a general analysis of Article 4 see Dariusz Adamski, "How Wide is 'the Widest Possible'? Judicial Interpretation of the Exceptions to the Right of Access to Official Documents Revisited" (2009) 46(2) Common Market Law Review 521-549; Adamski (n 15).

${ }^{20} \mathrm{See}$, for example, Technische Glaswerke Ilmenau (n 17), para 20; C-404/10 P, Commission v Éditions Odile Jacob, [2012] ECR 00000, paras 13, 18, 19; EnBW (n 7), para 17.

${ }^{21}$ State aid: Technische Glaswerke Ilmenau (n 17); mergers: Éditions Odile Jacob (n 20); C-506/08 P, Kingdom of Sweden v European Commission and MyTravel Group plc, [2011] ECR I-06237; C-477/10 P, European Commission v Agrofert Holding a.s., [2012] ECR 00000; general proceedings: Sweden v API (n 17). In C-28/08 P European Commission v Bavarian Lager Co Ltd, [2010] ECR I-06055 the Court also ruled on the applicability of Regulation (EC) No 45/2001 of the European Parliament and of the Council of 18 December 2000 on the protection of individuals with regard to the processing of personal data by the Community institutions and bodies and on the free movement of such data [2001] OJ L8/1.

${ }^{22}$ Technische Glaswerke Ilmenau (n 17).

${ }^{23}$ Council Regulation No 659/1999 of 22 March 1999 laying down detailed rules for the application of Article 108 of the Treaty on the Functioning of the European Union of the EC Treaty [1999] OJ L83/1.
} 
Commission and other institutions that the disclosure of documents in the administrative files would in principle undermine the purpose of the investigation. ${ }^{24}$ The institution need not to supply an explanation for every single document to which access is denied but it can define categories of documents to which similar considerations for denying access apply. ${ }^{25}$ This protection-friendly reading of Article 4 is contrasted by the finding in the same decision that "[t]he institution concerned must also supply explanations as to how access to that document could specifically and effectively undermine the interest protected by an exception laid down in [...] article [4(2).]"26

The CJEU subsequently refined this test in MyTravel, Éditions Odile Jacob and Agrofert, proceedings relating to merger investigations. ${ }^{27}$ In MyTravel, the CJEU specified the requirements for access to internal documents under Article 4(3). Article 4(3) distinguishes between documents drawn up for internal use (first subparagraph) and opinions for internal use as part of deliberations and preliminary consultations (second subparagraph). Internal documents of both types are protected from access during the investigation. For opinions (second subparagraph) the protection is extended to request that are made after the investigation has been concluded. The CJEU qualified a report of the Hearing Office, a note from DG Competition to the Advisory Committee and the file note concerning a site visit as internal documents in the sense of Article 4(3) second subparagraph. ${ }^{28}$ It reiterated that internal documents are only protected if the Commission indicates the specific reasons for why it considers that the disclosure of the administrative procedure would seriously undermine the decision-making process. ${ }^{29}$ More specifically, the Court demanded that the risk that disclosure would undermine the protected private or public interests must be reasonably foreseeable risk and not a purely hypothetical concern. ${ }^{30}$ The Commission failed to give specific reasons for why the documents in question ought to be protected and the case was referred back to the GC.

In Odile Jacob and Agrofert, two decisions with similar reasoning, the Court tightened the rules for access, applying the Merger Regulation. ${ }^{31}$ In contrast to MyTravel, the argument was dominated by the relationship between secrecy and access rights under the Merger Regulation, on the one hand, and the right of access under the Transparency Regulation, on the other. ${ }^{32}$ The Court found that the Transparency Regulation cannot be applied in isolation and the Merger rules that limit access to information must be taken into account. Although access under the Merger Regulation and access under the Transparency Regulation are legally distinct, "[...] they lead to a comparable situation from

\footnotetext{
${ }^{24}$ Technische Glaswerke Ilmenau (n 17), para 61.

${ }^{25}$ Technische Glaswerke IImenau (n 17), para 54.

${ }^{26}$ Technische Glaswerke Ilmenau (n 17), para 53.

${ }^{27}$ Éditions Odile Jacob (n 20); MyTravel (n 21); Agrofert (n 21).

${ }^{28}$ MyTravel (n 21), para 95.

${ }^{29}$ MyTravel (n 21), para 89.

${ }^{30}$ MyTravel (n 21), para 76.

${ }^{31}$ Council Regulation (EC) No 139/2004 of 20 January 2004 on the control of concentrations between undertakings (the EC Merger Regulation) [2004] OJ L 24/1. The CJEU also dealt with the previous merger regulation: Council Regulation (EEC) No 4064/89 of 21 December 1989 on the control of concentrations between undertakings [1989] OJ L 395/1.

${ }^{32}$ The Court also distinguished between the factual situations in the three merger-related requests for information. The request in MyTravel was made after the Commission decision was annulled and the appeal period against the General Court's decision had expired. In Agrofert the Commission had closed the merger proceedings and no remedies were sought against this decision. In Éditions Odile Jacob the request was made during an ongoing appeal procedure.
} 
a functional point of view. ${ }^{133}$ Allowing access on the basis of the Transparency Regulation would undermine the balance the Merger Regulation tries to achieve between access to information in order to assess concentrations and the protection of business secrets and confidential information. ${ }^{34}$ The Merger Regulation creates a general presumption that access to documents would undermine the purpose of the investigation and the commercial interests of the undertakings involved. Both the exception relating to the purpose of the investigation and the exception relating to commercial interests are closely related in merger proceedings. ${ }^{35}$ The Court reiterated that the institution concerned (Commission) must supply explanations as to how access to documents can specifically and actually undermine the protected interests. However, it is open to the institution to base its access-denying decision on general presumptions which apply to certain categories of documents. ${ }^{36}$

By the time the CJEU handed down its decisions in Agrofert and Éditions Odile Jacob, parties pursuing damages claims against cartel members had become interested in cartel-related information that is held by the European Commission. In EnBW the CJEU clarified that the principles it had developed for state aid and merger proceedings also apply to information requests relating to cartel investigations, quashing an earlier decision of the GC that had favoured a more lenient approach. ${ }^{37}$ The Commission, to justify the denial of access, must show that disclosure would specifically and actually undermine the protected interests in Article 4(2) and (3) of the Transparency Regulation. ${ }^{38}$ Similar to state aid and merger investigations a general presumption works in favour of the Commission that applies to both commercially sensitive information and the purpose of the investigation (first and third indent of Article 4(2)) as these exception rules are closely connected. ${ }^{39}$ The CJEU inferred from the existence of specific rules governing access to information in cartel investigations - Regulations $1 / 2003$ and773/2004 - that disclosure under the Transparency Regulation must be limited as it would otherwise undermine the specific access regime. ${ }^{40}$

\section{The EnBW access test}

The access test that was put forward by the CJEU in EnBW consists of three major elements. Firstly, the CJEU accepted that the Commission can define meaningful categories of documents that offer protection from disclosure for all documents that fall within a particular category. The Commission is not required to assess the protected interests for each and every document on an individual basis. ${ }^{41}$

\footnotetext{
${ }^{33}$ Éditions Odile Jacob (n 20), para 120.

${ }^{34}$ Éditions Odile Jacob (n 20), para 121.

${ }^{35}$ Éditions Odile Jacob (n 20), para 115; Agrofert (n 21), para 56

${ }^{36}$ Éditions Odile Jacob (n 20), para 116; Agrofert (n 21), para 57.

${ }^{37}$ The GC offered a narrower interpretation of the Article 4 exceptions in $C D C(n 7)$ and in $E n B W(n 7)$. The request for access to information in EnBW relates to the Commission Decision C(2006) 1766, Gas Insulated Switchgear (Case COMP/F/38.899), [2007] OJ C 75/19.

${ }^{38} \operatorname{EnBW}(\mathrm{n} 7)$, para 64.

${ }^{39} \operatorname{EnBW}(\mathrm{n} 7)$, para $79-81$.

${ }^{40} \mathrm{EnBW}$ (n 7), para 89f. Council Regulation (EC) No 1/2003 of 16 December 2002 on the implementation of the rules on competition laid down in Articles 81 and 82 of the Treaty [2003] OJ L 1/1; Commission Regulation (EC) No 773/2004 of 7 April 2004 relating to the conduct of proceedings by the Commission pursuant to Articles 81 and 82 of the EC Treaty [2004] OJ L 123/18.

${ }^{41}$ Technische Glaswerke Ilmenau (n 17), para 67; Agrofert (n 21), para 47; EnBW (n 7), para 65.
} 
Secondly, the CJEU created a rebuttable presumption, protecting all documents that fall within a particular category. It is assumed that the protection of commercial interests and the protection of the purpose of the investigation outweigh the right to public access. However, the CJEU also stated that the Commission must provide explanations as to how access to documents could specifically and actually undermine any of the protected interests. ${ }^{42}$ Thirdly, it is for the applicant to show that the interest in disclosure outweighs the interest in protection. Thus, the Court has shifted the burden of demonstration and proof from the access-denying institution to the applicant.

The first step under the access test is to define the protected categories. The Court rejected a duty of the Commission to individually assess documents in cartel proceedings and overturned the earlier decision of the GC in EnBW. The GC had held that the Commission did not assess the request "[...] in a concrete, specific and detailed manner, the other options that might be envisaged in order to limit its workload, or the reasons which could allow it to dispense with any concrete, individual examination, instead of adopting, where appropriate, a measure less restrictive of the applicant's right of access." ${ }^{43}$ The CJEU responded that "[...]it is open to the EU institution concerned to base its decisions in that regard on general presumptions which apply to certain categories of documents, as considerations of a generally similar kind are likely to apply to requests for disclosure relating to documents of the same nature [...]." ${ }^{44}$ It also argued that the access-seeking party had made a request for sets of documents and that the institution should be able to reply accordingly. ${ }^{45}$ In light of the size of the Commission's records - in the EnBW case the file contained roughly 1,900 documents - the CJEU accepted the Commission's classification of documents into six groups: ${ }^{46} 1$ ) documents provided in connection with an immunity or leniency application, including statements and documents submitted by undertakings; 2 ) requests for information and the parties' replies; 3 ) documents that were obtained during inspections; 4) the statement of objections and the parties' replies to it; 5) internal documents relating to the facts, including background notes and correspondence $(5 a)$ and internal procedural documents $(5 b) .{ }^{47}$

The threshold for sorting documents into these categories is a mere plausibility test. The CJEU " [...] found that it was 'plausible', in the light of the explanations provided by the Commission before it, that many of the documents fell within category 5(a) in the file in question[. I]t was not possible for the General Court, without erring in law, to criticise the Commission for failing to show specifically how those documents were covered by the exception provided for in the second subparagraph of Article 4(3) of Regulation No 1049/2001." ${ }^{\prime 8}$ The Court stressed that there is no need to assess individual documents or show specifically that these documents are protected by the exceptions of Article 4 as long as the categorisation is conceivable.

The problem with these categories is that they are rather broad and that the division is flawed. The CJEU should have divided the files into three groups, depending on how the Commission obtained the material in question. The first group should relate to documents that are submitted voluntarily.

\footnotetext{
${ }^{42} \mathrm{EnBW}(\mathrm{n} 7)$, para 64.

${ }^{43} \mathrm{EnBW}(\mathrm{GC})(\mathrm{n} 7)$, para 107.

${ }^{44} \operatorname{EnBW}(\mathrm{n} 7)$, para 65.

${ }^{45} \mathrm{EnBW}(\mathrm{n} 7)$, para $67 \mathrm{f}$.

${ }^{46}$ The CJEU approved of different categories in merger proceedings (communications between Commission, notifying parties and third parties, and internal documents), see Agrofert (n 21), para 47.

${ }^{47} \mathrm{EnBW}(\mathrm{n} 7)$, para 16.

${ }^{48} \mathrm{EnBW}(\mathrm{n} 7)$, para 115.
} 
The second group should consist of files that are submitted by firms under investigation that are exercising the right to defend themselves, i.e. mainly responses to the statement of objections. Finally, the third category should enclose documents that are retrieved via compulsory process, e.g. dawn raids, or that relate to situations where the companies are obliged to respond, e.g. requests for information. The first group of documents does not deserve protection whereas for the latter two groups the release should be considered more carefully. Voluntary submissions are based on a cost-benefit analysis of the undertaking concerned. Companies willing to submit information will normally take into account the possibility of disclosure and potential exposure to civil liability in follow-on damages actions. As successful leniency applicants receive a discount on the fine of up to 100 per cent, it is questionable if they deserve further protection..$^{49}$ If, on the other hand, firms are either obliged to hand over documents or exercise their right of defence, information should be protected. Firms have less control over those documents and they will not be able to consider the exposure to follow-on damages litigation. It is not apparent why voluntarily submitted information should obtain the same level of protection as information that had to be handed over to the Commission. Documents relating to leniency applications are part of a bargain and firms should take private actions into account before offering information.

It is often argued that the attractiveness of the leniency programme would be diminished, if information gained from whistle-blowers was disclosed..$^{50}$ If information from whistle-blowers was released, they could be disadvantaged compared to those who did not cooperate in the investigation. The disclosure of leniency-related material would undermine the purpose of the investigation (in the broader sense) and fall under the protection regime of Article 4(2) third indent. Although follow-on actions against cartels have gained traction in many EU Member States, the attractiveness of the EU leniency programmes has not suffered yet if one looks at the increasing number of decisions that are based on leniency applications. ${ }^{51}$ The argument that disclosure would undermine leniency has neither been proven nor been rejected on the basis of data as far as I am aware. It also not clear whether the prospect of future damages liability (or the legal costs associated with litigation) can indeed offset the incentives provided by the large discount on the fine or whether these are considerations that are taken into account at all when firms make a decision to cooperate. Finally, all addressees of the Commission's decision are able to use the confidential version of the decision that normally contains parts of the leniency submission. In subsequent civil litigations firms that have violated the law will find themselves in a better position with better information than those firms that have yet to prove that they have suffered damages as a consequence of a cartel. Assuming that every individual should have the right to sue for compensation if Article 101 TFEU was breached, ${ }^{52}$ the definition of categories does not convince and should be reconsidered. ${ }^{53}$

The issue of defining meaningful categories must be separated from the second step; that is creating an assumption of protection in favour of the categories outlined above. The CJEU established a rebuttable presumption that documents in these categories relate to protected commercial interests

\footnotetext{
${ }^{49}$ In the same vein Donau Chemie (n 7), para 47.

${ }^{50}$ Netherlands (n 7), para 41; T-534/11 Schenker AG v European Commission [2014] ECR I-0000, para 56.

${ }^{51}$ See European Commission, Cartel Statistics (October 2014) available at: http://ec.europa.eu/competition/cartels/statistics/statistics.pdf.

${ }^{52}$ Courage (n 9); Manfredi (n 9).

${ }^{53}$ See also for the consequence of a refusal to disclose important documents Donau Chemie (n 7), para 47.
} 
or, if disclosed, may endanger the purpose of the investigation. ${ }^{54}$ Table 1 outlines the categories of documents the Court accepted in EnBW and the disclosure exemptions provided for in Article 4.

[Insert Table 1 about here]

All categories in Table 1, apart from category 5b, are protected from disclosure by at least two exemptions: commercial interests and the risk that disclosure would undermine the purpose of the investigation are presumed to outweigh the applicant's interest in disclosing documents from categories 1 to 4 . The most powerful exemption for rejecting access to documents is arguably that the release of information would undermine the purpose of the investigation. This exception applies to all classes of documents. In the past, the GC and the CJEU disagreed on how to interpret the purpose of the investigation. The GC preferred a narrow reading in two earlier decisions, ${ }^{55}$ referring to the particular investigation in question. The purpose of an investigation is to determine whether Article 101 or 102 TFEU has been breached. It held that once a decision is handed down, the purpose of this investigation can no longer be compromised by, for example, making confidential material accessible. ${ }^{56}$ In $C D C$ the Fourth Chamber of the GC found that the purpose of this exemption is not to protect the investigation as such but the purpose of a specific investigation into anticompetitive conduct. ${ }^{57}$ These arguments did not convince the Sixth Chamber of the GC in Netherlands and the CJEU in EnBW..$^{58}$ Documents can only be accessed when the decision is final and all appeals have been dealt with:

"Contrary to the General Court's finding [...], a proceeding under Article 81 EC cannot be regarded as closed once the Commission's final decision has been adopted irrespective of any possible future judgment by the EU judicature annulling that decision. [T]he annulment of such a decision may lead the Commission to resume its investigations with a view to adopting, if appropriate, a new decision on the application of Article 81 EC [...], and may therefore lead that institution to reuse information in the file relating to the annulled decision or to supplement the file with other information in the exercise of the powers conferred on it by Regulation No 1/2003. Consequently, investigations relating to a proceeding under Article 81 EC may be regarded as completed only when the decision adopted by the Commission in connection with that proceeding is final. ${ }^{159}$

Consequently, all categories outlined in Table 1 are presumed to fall under the protection of Article 4(2) third indent of the Transparency Regulation. Their disclosure would undermine the purpose of the investigation for the entire time span of any potential appeal proceedings. A typical cartel case in the European Union takes about a decade from the time the investigation starts until the end of the

\footnotetext{
${ }^{54} \operatorname{EnBW}(\mathrm{n} 7)$, para 78.

${ }^{55} \mathrm{CDC}$ (n 7); $\operatorname{EnBW}(\mathrm{GC})$ (n 37).

${ }^{56} C D C(\mathrm{n} 7)$, para 59-62; EnBW (GC) (n 37), para 119.

${ }^{57} \mathrm{CDC}(\mathrm{n} 7)$, para 59. The claimant-friendlier approach in $\mathrm{CDC}$ may be explained by the fact that CDC sought only access to the table of contents of the Commission's file.

${ }^{58}$ Netherlands (n 7), para 57; EnBW (n 7), para 98.

${ }^{59} \mathrm{EnBW}(\mathrm{n} 7)$, para 99.
} 
appellate process. ${ }^{60}$ Unless the period of limitation for bringing a claim in the national court is suspended, this would bar follow-on damages actions against cartels in most Member States, assuming that claimants require some information that is in the hands of the defendants or the European Commission. ${ }^{61}$ But even if the period of limitation is suspended, the resulting delays may argue against bringing a follow-on claim for damages. ${ }^{62}$

Even if applicants can successfully disprove the strong presumption regarding the purpose of the investigation, they will have to rebut the closely connected presumption that documents contained in categories 1 to 4 also protect commercial interests. Commercial interests are defined broadly, including information such as "[...] the commercial strategies of the undertakings concerned, their sales figures, their market shares or their business relations [...]." ${ }^{13}$ The Court further states that "[...] the exceptions relating to the protection of commercial interests and the protection of the purpose of investigations are, in such a procedure, closely connected [...]." ${ }^{\prime 64}$ The Commission argued for an even wider interpretation of commercial interest including documents that contain "[...] information on the commercial activities of the undertakings concerned, to which those undertakings would not have granted access in that form outside cartel proceedings. ${ }^{\prime \prime 5}$ In essence, the Court declared all information 'commercially sensitive' that would potentially be relevant in a follow-on damages claim. The close connection between commercial interests and information that could undermine the purpose of the investigation strengthen the presumption of non-disclosure.

The CJEU justifies the broad reading of the exceptions and the creation of presumptions in favour of the authorities with the need to consistently apply the Transparency Regulation with Regulations $1 / 2003$ and $773 / 2004 .{ }^{66}$ The latter two instruments provide for specific access rights during competition law investigations. The Court made clear that there is no ranking between these legal instruments. However, the CJEU tied the interpretation of the Transparency Regulation to the reading of the more specific access rights laid out in Regulations $1 / 2003$ and 773/2004. ${ }^{67}$ Article 27(2) of the Modernisation Regulation 1/2003 allows firms under investigation to access the Commission's files but for business secrets of other companies and internal documents. Information received during investigations must not be disclosed according to Article 28 of the Modernisation Regulation. Articles 6, 8, 15 and 16 of Regulation 773/2004 govern the complainant's access to information as well as access for those parties issued with a statement of objections. Similarly to Article 27(2) of the Modernisation Regulation, business secrets, internal documents and communication between the competition authorities are to be protected from disclosure. From those provisions the CJEU draws the conclusion that parties involved in antitrust proceedings

\footnotetext{
${ }^{60}$ Christopher Harding, Alun Gibbs, "Why Go to Court in Europe? An Analysis of Cartel Appeals 1995-2004" 30(3) 2005 European Law Review 349, 364.

${ }^{61}$ Article 10(4) of the Damages Directive suspends the running of the period of limitations until the decision of the Competition Authority becomes final.

62 In a damages claim following the Commission's Airfreight decision (Commission Decision of 9 November 2010, Airfreight, case COMP/39258, not published yet) in the English High Court, Peter Smith J. emphasised he problems caused by delayed access to information due to claims of confidentiality (unrelated to the Transparency Regulation). See Emerald Supplies v British Airways [2014] EWHC 3513 (Ch), para 3.

${ }^{63}$ EnBW (n 7), para 79. See also Netherlands (n 7), para 34

${ }^{64} \operatorname{EnBW}(\mathrm{n} 7)$, para 79.

${ }^{65} \mathrm{EnBW}(\mathrm{n} 7)$, para 53.

${ }^{66}$ This argument was also brought forward in earlier cases. Éditions Odile Jacob (n 17); Agrofert (n 21).

${ }^{67} \mathrm{EnBW}(\mathrm{n} 7)$, para 86.
} 
generally enjoy restricted access rights and that the Transparency Regulation has to be interpreted accordingly. It concludes that "[i]f persons other than those with a right of access under Regulations Nos 1/2003 and 773/2004, or those who enjoy such a right in principle but have not used it or have been refused access, were able to obtain access to documents on the basis of Regulation No 1049/2001, the access system introduced by Regulations Nos 1/2003 and 773/2004 would be undermined [...]" ${ }^{68}$ The CJEU acknowledges that the right to access under the Transparency Regulation is legally distinct from the other access rights. But it claims that these are comparable situations from a functional point of view. ${ }^{69}$

The presumption of protection based on the Modernisation Regulation and Regulation 773/2004 is rather restrictive. In the spirit of the Transparency Regulation the CJEU should have made a clear distinction between closed investigations and open investigations, including appeal proceedings that are affected by the provisions in Regulations $1 / 2003$ and 773/2004. The Commission should be able to rely on presumptions to reject access requests in on-going investigations but the presumptions should not be used once the investigation is closed. The competition-specific Regulations deal with proceedings that are ongoing, i.e. proceedings in which the Commission has not yet handed down a decision or, arguably, proceedings in which an appeal is still pending. A presumption in favour of the Commission to safeguard the purpose the investigation while it is ongoing seems to be justifiable. After the decision has been handed down, the Commission should not be able to rely on the presumption of protection. Such a far-reaching presumption also undermines the purpose of the Transparency Regulation which promotes the widest possible access to information. While presumptions may be needed, the analogy the Court uses to justify them is flawed. ${ }^{70}$ The CJEU first developed the presumption of protection with regards to merger proceedings and state aid investigations. In those proceedings the undertakings involved are not normally found guilty, i.e. they have not breached the law. The addressees of a decision relating to Articles 101 or 102 TFEU, however, have usually violated competition law rules and were therefore subject to an investigation. This difference should confer more weight on the access rights in, for example, cartel investigations as compared to merger or state aid proceedings.

This approach - permitting rebuttable presumptions to protect groups of documents - is somewhat softened as the institution concerned must supply an explanation as to how access to the document in question could specifically and actually undermine the protected interest: ${ }^{71}$ "[I]t is not sufficient, in principle, for that document to be covered by an activity mentioned in Article 4(2) and (3) of Regulation No 1049/2001. The institution concerned must also provide explanations as to how access to that document could specifically and actually undermine the interest protected by an exception laid down in that article [...]." ${ }^{72}$ However, the existence of presumptions and the requirement to provide a specific explanation for why the documents cannot be accessed are hard to reconcile. These two statements may make sense if the concrete and individual assessment of single documents or plausible groups of documents under Article 4 is the rule whereas the assumption of protection is the exception, overriding the general rule. However, the decision practice of the CJEU

\footnotetext{
${ }^{68} \mathrm{EnBW}(\mathrm{n} 7)$, para 88.

${ }^{69} \mathrm{EnBW}(\mathrm{n} 7)$, para 89.

${ }^{70}$ See for the analogy EnBW (n 7), para 92.

${ }^{71} \mathrm{EnBW}(\mathrm{n} 7)$, para 64.

72 See also Technische Glaswerke Ilmenau (n 17), para 53; Éditions Odile Jacob (n 20), para 116; Agrofert (n 21), 57.
} 
suggests, that the assumption of protection has become the rule regarding competition law investigations.

In the final step of the access test, the applicant has to demonstrate that a specific document is not covered by the presumptions, or that there is an overriding public interest in the disclosure of the document. ${ }^{73}$ This means that the applicant has to rebut the presumptions that disclosure would undermine the purpose of the investigation or put commercial interests at risk. The applicant's interests outweigh the presumption of protection if he can show that it is necessary to access the Commission's file. ${ }^{74}$ The case law does not specify what is deemed necessary in order to access the information in the Commission's records. In the final part of the EnBW decision, the CJEU held that the applicant did not offer any evidence to show in what way the documents requested were necessary for bringing a claim in the national court or that there was no other way of obtaining evidence to support a damages claim. ${ }^{75}$ The mere fact that the applicant intends to initiate litigation for the loss suffered from breaches of Article 101 TFEU or that the applicant has an interest in obtaining compensation does not constitute an overriding public interest. ${ }^{76}$

The CJEU finds that limitations of the right to access information can be reconciled with the right to compensation for the violation of EU competition law it had expressed in Courage and Manfredi. ${ }^{77}$ In these case it was stressed that every individual has an effective right to redress in the national courts. The CJEU held that "[...] there is no need for every document relating to a proceeding under Article 81 EC to be disclosed to that claimant on the ground that that party is intending to bring an action for damages, as it is highly unlikely that the action for damages will need to be based on all the evidence in the file relating to that proceeding [...]." ${ }^{17}$ It is interesting to note that the Court made a similar statement in proceedings related to disclosure of confidential documents in the national courts. $^{79}$

The CJEU's interpretation of Article 4 of the Transparency Regulation has effectively reversed the burden of proof as it is now for the applicant to show that access to a particular document is needed. The shifting of the burden from the Commission to the applicant makes it unlikely that documents for which confidentiality is claimed will be revealed. In EnBW the CJEU made clear that it is for the applicant to show that access is necessary and in the public interest in order to outweigh the strong presumptions in favour of the investigation and commercial interests.

One can argue that the GC's recent ruling in Schenker has slightly relaxed the conditions for access to information. ${ }^{80}$ The applicant sought access to the full file, full decision and, alternatively, to the nonconfidential decision of the Commission. The GC held that the Commission had correctly denied access to information that would undermine the purpose of the investigation and material that is commercially sensitive. However, it also found that the Commission should have granted partial

\footnotetext{
${ }^{73}$ EnBW (n 7), para 100; Technische Glaswerke Ilmenau (n 17), para 62; Éditions Odile Jacob (n 17), para 126; Agrofert (n 21), para 68.

${ }^{74} \mathrm{EnBW}(\mathrm{n} 7)$, para 107.

${ }^{75} \mathrm{EnBW}(\mathrm{n} 7)$, para 132

${ }^{76} \mathrm{EnBW}(\mathrm{n} 7)$, para 108.

${ }^{77}$ Courage (n 9); Manfredi (n 9).

${ }^{78} \mathrm{EnBW}(\mathrm{n} 7)$, para 106.

${ }^{79}$ Donau Chemie (n 7), para 33. See also subsection III.

${ }^{80}$ Schenker (n 50).
} 
access according to Article 4(6) to the version of the decision that none of the undertakings has found objectionable on confidentiality grounds. ${ }^{81}$ Normally, the Commission negotiates a redacted version of the decision with the addressees of that decision. This is a protracted process that can take many years before coming to a conclusion. ${ }^{82}$ While the time limit for enabling access to partial information is normally 15 days and in exceptional cases another 15 days according to Article 8(1)(2), the GC found that almost nine months between the handing down of the infringement decision and the denial of access is not unreasonable in the light of the number of confidentiality requests. ${ }^{83}$ Arguably, this ruling will provide incentives for addressees of the Commission's decision to challenge all parts of the decision, leaving the applicant with nothing to gain access to. It is also questionable whether the redacted version of the decision is meaningful at all and, thus, helpful for any potential follow-on damages claim. In the English Emerald Supplies case, Justice Peter Smith found that the version of the Commission's decision the defendants had been allowed to redact turned out to be "completely useless". ${ }^{84}$

Overall, a close look at the jurisprudence of the CJEU and GC reveals that access to documents under the Transparency Regulation is severely restricted if these documents have been part of a competition investigation. Competition authorities can group these documents and claim the existence of presumptions to protect them from disclosure. It is for the potential applicant to show that access is necessary and there is a supporting public interest that outweighs the concerns regarding commercially sensitive information and the purpose of the investigation. As I have shown, it is unlikely that applicants will get access to sensible information. The restrictions regarding access to information will reduce the incentives to bring follow-actions, i.e. claims that are brought during or after a public investigation. It appears that with regards to private actions the courts and the Commission favour stand-alone over follow-on actions. As we will see in the next section, a similar conclusion can be drawn when access to documents in the national courts is concerned.

\section{Access to documents before the national courts}

Firms that seek access to documents may also use the national courts of the Member States and the national procedure to obtain access to material from the European Commission or a national competition authority. This section focuses on the EU rules governing access to leniency documents in the national courts. It analyses the framework that the CJEU has created with its Pfleiderer and Donau Chemie rulings, the application of the Pfleiderer test in Germany and England, and the new Damages Directive and the impending changes for national disclosure regimes, especially in England and Germany. I will show that the Damages Directive creates a strict disclosure regime in follow-on damages actions with regards to the documents that are or were in the hands of the competition authorities

\footnotetext{
${ }^{81}$ Schenker (n 50), para 137.

${ }^{82}$ See Emerald Supplies ( $\mathrm{n} 62$ ).

${ }^{83}$ Schenker (n 50), para 134.

${ }^{84}$ Emerald Supplies (n 62), para 31. See subsection III.
} 


\section{The framework}

The CJEU laid out the rules governing access to confidential information in Pfleiderer and Donau Chemie, two preliminary references made by a German and an Austrian court respectively. ${ }^{85}$ In the former case, the German court dealt with a national rule that permitted 'aggrieved parties' to access documents held by the German competition authority. ${ }^{86}$ The German competition authority, the Federal Cartel Office, partly denied the initial application for disclosure. The District Court of Bonn, dealing with the complaint, asked the CJEU whether access to inter alia leniency documents based on the German rule was compatible with Articles 11 and 12 of Regulation $1 / 2003 .{ }^{87}$ Articles 11 and 12 provide for close cooperation and the mutual exchange of information between the Commission and the national competition authorities of the Member States. ${ }^{88}$

The CJEU rejected both an outright refusal to access as well as an unconditional disclosure of leniency documents. The Court observed that leniency programmes serve the objective of effective application of Articles 101 and 102 TFEU. ${ }^{89}$ The disclosure of leniency documents would undermine the effective application of EU competition rules. However, every individual has the right to claim compensation for harm suffered from a violation of EU competition rules. ${ }^{90}$ This principle would be undermined if there was a strict ban on the disclosure of leniency documents. The national courts must weigh the arguments in favour and against a release of leniency documents and decide on a case by case basis whether access should be granted. While weighing the different interests the national courts must respect the principles of equivalence and effectiveness. ${ }^{91}$ The principle of equivalence requires that the rules governing the enforcement of the EU right to damages must not be less favourable than the rules governing the enforcement of a similar national right. The standard of effectiveness requires that national rules must not make it practically impossible or excessively difficult to enforce a Treaty right.

In Donau Chemie the CJEU confirmed the case by case approach it had established in Pfleiderer. The Austrian Higher Regional Court of Vienna had asked the CJEU whether a provision of the Austrian Cartel Law was compatible with the EU right to damages for violations of competition law. The Austrian Cartel Law prohibited third-party access to the case files of the Cartel Court, containing inter alia leniency documents, without the consent of the parties concerned. ${ }^{92}$ It overrode a more lenient access regime according to general civil procedural rules. ${ }^{93}$ The Cartel Law de facto barred access to leniency and other important documents in follow-on damages litigation as parties to

\footnotetext{
${ }^{85}$ Pfleiderer (n 7); Donau Chemie (n 7).

${ }^{86}$ Section 406e of the German Code of Criminal Procedure (Strafprozessordnung) permits access to documents held by a court. Section 46(1) of the Law on Administrative Offences (Gesetz über Ordnungswidrigkeiten) applies these principles to administrative procedures, including inter alia proceedings before the German competition authority.

${ }^{87}$ The German court also sought advice on the compatibility with Articles 10(2) and 3(1)(g) of the Treaty establishing the European Community, [2002] OJ C325/1.

${ }^{88}$ Pfleiderer (n 7), para 17.

${ }^{89}$ Pfleiderer (n 7), para 25.

${ }^{90}$ Courage (n 9); Manfredi (n 9).

${ }^{91}$ Courage (n 9) para 47; Manfredi (n 9) para 62. See also joined cases C-6/90 and C-9/90 Francovich v Italian Republic [1995] ICR 722, para 43.

92 Section 39(2) of the Austrian Cartel Law.

${ }^{93}$ Section 219 of the Austrian Code of Civil Procedure.
} 
competition law investigations are unlikely to consent to a disclosure of documents that would potentially increase their exposure to civil liability. The CJEU rejected the rigid Austrian rule because it is liable to make the exercise of the right to compensation excessively difficult, violating the principle of effectiveness. ${ }^{94}$ The Court confirmed its earlier decision in Pfleiderer that the national court must weigh the different interests. ${ }^{95} \mathrm{~A}$ strict rule that either prohibits or indiscriminately allows access would undermine the effective application of the EU competition law rules. ${ }^{96}$

These decisions have established a weighing test the national courts must apply when considering whether third parties should be given access to leniency and other documents that are or were in the hands of the competition authority. First, the national court should appraise the interest in obtaining access to the documents in question. ${ }^{97}$ It should specifically take into account the alternatives the access-seeking party has to access information. Second, the potential harm that can be caused by the disclosure of confidential material must be considered. The question is whether the disclosure can harm 'public interests' or the 'legitimate interests' of other parties. ${ }^{98}$ The degree of harm or the probability with which the harm will occur has not been determined by the CJEU. However, the Court pointed out that it will not suffice to reject access due to "[...] a risk that access to evidence [...] may undermine the effectiveness of a leniency programme [...]." ${ }^{\prime 99}$ This probably means that a remote risk to leniency programmes must not prevail over the applicant's interest in disclosure. If, however, access may 'actually undermine' the public interest relating to the effectiveness of the national leniency programme, the CJEU held that a refusal to access may be justified. ${ }^{100}$ The threshold for harm to public enforcement seems to be located between purely theoretical concerns and actual harm. The CJEU seems to have phrased the test in favour of the access seeking parties: ${ }^{101}$

"[...] the fact that such a refusal is liable to prevent those actions from being brought, by giving the undertakings concerned, who may have already benefited from immunity,[...] an opportunity also to circumvent their obligation to compensate for the harm resulting from the infringement of Article 101 TFEU, to the detriment of the injured parties, requires that refusal to be based on overriding reasons relating to the protection of the interest relied on and applicable to each document to which access is refused." ${ }^{102}$

When national courts assess requests for disclosure on a case-by-case basis, the CJEU appears to impose a duty on the national courts to evaluate documents individually ("applicable to each document") rather than to appraise categories of documents. Whether this is what the Court had in mind or this is a practical solution, given the size of case files, remains to be seen. National courts are being given discretion to determine legitimate private and public interests. The CJEU points out

\footnotetext{
${ }^{94}$ Donau Chemie (n 7), para 39

${ }^{95}$ Donau Chemie (n 7), para 30.

${ }^{96}$ Donau Chemie (n 7), para 31.

${ }^{97}$ Donau Chemie (n 7), para 44; Pfleiderer (n 7), para 30.

${ }_{98}$ Donau Chemie (n 7), para 45; Pfleiderer (n 7), para 30.

${ }^{99}$ Donau Chemie (n 7), para 46.

${ }^{100}$ Donau Chemie (n 7), para 49.

${ }^{101}$ See also Francesco Rizzuto, "The Procedural Implication of Pfleiderer for the Private Enforcement of European Union Competition Law in Follow-up Actions for Damages" (2011) 4(3) Global Competition Litigation Review 116-124.

${ }^{102}$ Donau Chemie (n 7), para 47.
} 
that EU law confers other rights on individuals worth protecting, including the right to protection of professional secrecy or of business secrets, or the right to the protection of personal data. While these are actual rights, the CJEU also considers pure interests as worthy of protection. In Donau Chemie, it defines the protection of public enforcement, especially through cooperation with firms, as a public interest. ${ }^{103}$ While the weighing approach allows national courts to take into account the various interests, including the difficulties of obtaining evidence from other sources, it has also created uncertainty and hard to handle case-by-case approach. ${ }^{104}$ The high value that is placed on the protection of leniency programmes and, thus, effective public competition law enforcement, creates significant barriers for claimants to access information in follow-on damages litigation. Since it is left to the national courts to weigh the interests in question and assure that the principle of effectiveness is observed, I shall investigate how the principles from Pfleiderer and Donau Chemie are applied in the national courts. In the next section, I will look at the recent case law of the English High Court and the application of the weighing test in Germany.

\section{The Pfleiderer/Donau Chemie test applied}

In this section, I will briefly look at the reception of the weighing test in the English High Court and the German courts. Courts in both jurisdictions do not allow indiscriminate third party access to confidential documents, thus limiting the information that is made available to follow-on damages claimants.

The first court to implement the Pfleiderer decision was the German District Court of Bonn that had made the preliminary reference to the CJEU. German civil procedure rules do not provide for general disclosure of documents in civil litigation. However, aggrieve parties are able to inspect the files of the competition authority. ${ }^{105}$ In its preliminary reference the District Court had indicated that it intended to allow access to the leniency statement and related material in the file of the competition authority. After the CJEU's decision, however, the District Court held that the interest in protection outweigh the applicant's interest in disclosure. ${ }^{106}$ Access to files of the authority can be denied if this would undermine the purpose of the investigation in question or another investigation. ${ }^{107}$ The District Court re-echoed the arguments of the CJEU and Advocate General Mazák in Pfleiderer. ${ }^{108}$ The purpose of the public investigation is to uncover and pursue breaches of competition law. The (national) leniency programme is a crucial tool to enforce the competition rules. The disclosure of voluntarily submitted information to third parties may reduce the incentives for firms to cooperate with the competition authorities. This applies to ongoing and future investigations. ${ }^{109}$ The District Court pointed out that the cooperating firm's interest in the protection

\footnotetext{
${ }^{103}$ Donau Chemie (n 7), para 33.

${ }^{104}$ Amit Kumar Singh, "Pfleiderer: Assessing its Impact on the Effectiveness of the European Leniency Programme" (2014) 35(3) European Competition Law Review 110, 122.

${ }^{105}$ See $\mathrm{n} 86$ above.

${ }^{106}$ Amtsgericht Bonn, 18 January 2012, Az. 51 Gs 53/09, Pfleiderer, para 26.

${ }^{107}$ Section 406e(2)2 Code of Criminal Procedure.

${ }^{108}$ Amtsgericht Bonn (n 106), para 32f; Opinion of Advocate General Mazák, C-360/09 Pfleiderer v Bundeskartellamt.

${ }^{109}$ Amtsgericht Bonn (n 106), para 34.
} 
of voluntarily submitted material outweighs the interests of the applicant. Interestingly, the Court held that access to the overcharge calculations (of the German Federal Cartel Office) are also protected. ${ }^{110}$ It is not quite clear how those estimates of the cartel harm would have affect any of the protected interests the Court relied on. In a similar case, the Higher Regional Court of Düsseldorf confirmed that public and private interests argue against the disclosure of the Cartel Office's file or the leniency material but that a non-confidential version of the decision must be made available to the applicant. ${ }^{111}$ The applicant had a legitimate interest in the disclosure of information to support a damages claim against the cartelists. However, the protection of personal data and professional secrets, the legitimate expectation that the leniency application is being treated confidential and the effectiveness of public law enforcement outweigh the applicant's interest and bar access to the file or the leniency application. ${ }^{112}$ These concerns do not apply to the disclosure of a redacted, nonconfidential version of the decision. ${ }^{113}$

The English High Court applied the Pfleiderer weighing test in National Grid and Emerald Supplies. ${ }^{114}$ National Grid integrates Pfleiderer in the English rules of civil disclosure whereas Justice Peter Smith expressed some concerns regarding the confidentiality of Commission decisions in Emerald Supplies. Claimants in the English courts benefit from disclosure in the High Court of Justice and the Competition Appeal Tribunal (CAT). ${ }^{115}$ Parties must allocate and make accessible documents which are or have been in their possession and that are material to the case. Rule 31 of the Civil Procedure Rules (CPR) includes documents the claimant or defendant has inspected or has had the right to inspect. ${ }^{116}$ The disclosing party is to reveal information that is both supportive of its case and potentially damaging. ${ }^{117}$ General standard disclosure is broad but can be limited by, for example, more targeted disclosure relating to individual allegations or issues. ${ }^{118}$ The scope of disclosure is also reduced by privileges the defendant can invoke. However, material that has been submitted to a competition authority for leniency or settlement purposes is not privileged under English and Welsh law. The legal advice and the litigation privilege protect verbal or written messages exchanged

\footnotetext{
${ }^{110}$ Amtsgericht Bonn (n 106), para 42. The fining rules have changed with the $7^{\text {th }}$ amendment of the German Competition Act and the cartel overcharge will no longer be calculated.

111 Oberlandesgericht Düsseldorf, 22 August 2012, V-4 Kart $5+6 / 11$ (OWi), Kaffeeröster.

112 Oberlandesgericht Düsseldorf ( $n$ 111), para 48 and 62.

${ }^{113}$ The decision of the Higher Regional Court of Hamm may have opened a backdoor for disclosure. The Higher Regional Court allowed another court, the Regional Court of Berlin, to access the prosecutor's case files, including the leniency application, while the latter court is dealing with a damages claim against the members of the elevators and escalators cartel (Elevators and Escalators (Case COMP/E-1/38.823) [2008] OJ C 75/19). This does not mean direct access for claimants as the Regional Court will probably have to assess this question separately, presumably applying the Pfleiderer weighing test. See Oberlandesgericht Hamm, 26 November 2013, 1 Vas 116/13 - 120/13 and 122/13.

${ }^{114}$ National Grid Electricity Transmission PIC V. ABB Ltd and others [2012] EWCA 869 (National Grid II). This is an action following the gas insulated switchgear cartel. Gas Insulated Switchgear (Case COMP/F/38.899) [2007] OJ C 75/19. Emerald Supplies ( 62 )

${ }^{115}$ The Competition Appeal Tribunal is a specialist court with currently limited jurisdictions for monetary follow-on claims. Section 19 of the Competition Appeal Tribunal Rules 2003 (SI 2003 No.1372) enables the CAT to order the production of documents.

${ }^{116}$ CPR 31.8(2).

${ }^{117}$ CPR 31.6.

${ }^{118}$ See the limited disclosure ordered by Justice Roth in Infederation Ltd v Google Inc [2013] EWHC 2295 (Ch).
} 
between lawyer and client and communication for the preparation of litigation. ${ }^{119}$ Documents that competition authorities deem confidential, such as responses to statement of objections, leniency and settlement statements or the confidential version of the decision, are unlikely to benefit from these privileges and have to be assessed according to the principles laid out in Pfleiderer and Donau Chemie.

In National Grid the applicants sought access to the confidential version of the Commission's decision, the responses to the Commission's statement of objections and the responses to information requests. ${ }^{120}$ Justice Roth concluded that access to some redacted documents should be granted, and he ordered the release of information within a confidentiality ring. He applied the Pfleiderer test to both documents held by the national competition authorities and the European Commission, extending the scope of Pfleiderer to the latter. ${ }^{121} \mathrm{He}$ first asked whether the disclosure would increase the leniency applicant's exposure to liability compared to non-cooperating parties. ${ }^{122}$ Secondly, he determined whether the gravity and duration of the infringement outweigh the concerns regarding the deterrence of potential leniency applicants. Finally, the court stipulated that disclosure must be proportionate.

With regards to the first step - exposure to liability - Justice Roth held that all cartelists were codefendants. Consequently, there was no risk that the leniency applicant would potentially be liable for the entire harm. If the release of documents would single out the leniency applicant as the only defendant and enable non-cooperating co-defendants to escape liability, this may argue against the disclosure of confidential files. ${ }^{123}$ On the second step, assessing the gravity and duration of the infringement, it was denoted that the serious nature of the cartel and its duration of almost 16 years constituted factors in favour of disclosure. ${ }^{124}$ For the final proportionality test, Justice Roth took into account whether the requested documents were relevant for the claimant's case and whether the requested documents were available from other sources. It was held that the information could not be obtained from another source without excessive difficulties for the claimant. ${ }^{125}$

Justice Roth ordered limited disclosure within a confidentiality ring. He inspected the material in question and decided that not all documents were relevant for a fair disposal of the claim. He ruled that the claimant is to gain partial access to the confidential version of the Commission's decision and limited access to ABB's response to the Commission's information request. It was also held that the public enforcement proceedings were no longer ongoing despite pending appeals. For his rather access-friendly interpretation, Justice Roth relied on earlier Commission documents, in particular the

\footnotetext{
${ }^{119}$ See also section 30 of the Competition Act 1998. The legal advice privilege does not cover in-house communication. C-550/07 P Akzo Nobel Chemicals Ltd and Akcros Chemicals Ltd v European Commission [2010] ECR I-08301.

${ }^{120}$ National Grid II (n 114).

${ }^{121}$ National Grid II (n 114), para 26.

122 Roth J. dismissed the 'legitimate expectation of protection' as a factor to be taken into account. National Grid II (n 114), para 34. The German Higher Regional Court of Düsseldorf found this expectation to be legitimate. Oberlandesgericht Düsseldorf (n 111), para 48 and 62.

${ }^{123}$ National Grid II (n 114), para 35.

${ }^{124}$ National Grid II (n 114), para 37.

${ }^{125}$ National Grid II (n 114), para 44.
} 
Commission's White Paper on Damages Actions in which the Commission strongly support follow-on damages actions. ${ }^{126}$

The Emerald Supplies case, pending in the High Court, illustrates that access to confidential information is not only problematic with regards to the definition of confidentiality but that it is also a time-consuming and protracted affair that may reduce the incentives to bring a follow-on claim. ${ }^{127}$ The claimants seek access to the confidential version within a confidentiality ring of the Commission's Airfreight decision. After a futile attempt to agree on redactions that would not render the confidential decision of the Commission completely useless, Justice Peter Smith felt that the release of the un-redacted decision without leniency material would be the only satisfactory conclusion. Unlike Justice Roth, he did not consider the Pfleiderer weighing test in much detail, and he refused to redact the document himself. ${ }^{128}$ He quoted extensively from the Commission's opinion submitted in William Morrison Supermarkets, in which the Commission did not object on principle to the release of a confidential version of the decision within a confidentiality ring. ${ }^{129}$

The principles of Pfleiderer and Donau Chemie do not pose major legal challenges for the German and English courts. The national courts do not allow general access to leniency documents. Confidentiality rings and redactions by the courts seem to address some issues with regards to nonleniency material. However, it seems difficult to efficiently implement these principles in daily praxis, avoiding delays for claimants in follow-on cases. Justice's Roth decision in in National Grid has added some flesh to the bones of the Pfleiderer weighing test. Elements such as potential exposure to civil liability, the gravity of the infringement and the availability of evidence resemble something akin to a checklist that could be used to determine the strength of the access request. It seems that the English High Court feels more restricted by the limitations imposed on the, presumably wider, national disclosure rules compared to the German courts. Claimants will face difficulties when seeking the disclosure of confidential material in follow-on cases in both jurisdictions, especially with regards to leniency documents. The national disclosure rules based on Pfleiderer and Donau Chemie will soon give way to the more rigid confidentiality rules of the Damages Directive as I will demonstrate in the next subsection.

\section{The Damages Directive}

The Damages Directive that was recently adopted by the European Parliament and the Council will change the framework for access to documents in the national courts. ${ }^{130}$ This section shows that the test for access to confidential information under the Transparency Regulation and the test according to the Damages Directive have converged to a considerable degree, making it more difficult for

\footnotetext{
${ }^{126}$ White Paper (n 10).

${ }^{127}$ Emerald Supplies (n 62), para 22. Four years after it had made its Airfreight decision, the Commission has not yet published a non-confidential version thereof.

${ }^{128}$ Emerald Supplies (n 62), para 103 and 42.

${ }^{129}$ Emerald Supplies (n 62), para 105. Opinion of the European Commission, Interchange fee litigation before the Judiciary of England and Wales: Wm. Morrison Supermarkets plc and Others v MasterCard Incorporated and Others (Claim Nos. 2012/699; 2012/1305-1311).

${ }^{130}$ The European Parliament adopted the proposal on 17 April 2014 and the EU Council of Ministers on 10 November 2014.
} 
follow-on claimants to access information. The Damages Directive is likely to discourage requests for information that was or is in the hands of the competition authority and, thus, will dampen the incentives to bring follow-on damages claims.

Pursuant to Article 5 of the Damages Directive, the Member States are to introduce inter partes disclosure procedures in national laws in order to alleviate civil enforcement of EU competition law rules. ${ }^{131}$ National courts shall be given the powers to order the disclosure of evidence upon request of the claimant if the claimant has presented a reasonable justification for the request, the required documents are relevant, precisely defined (as much as possible) and the disclosure satisfies the proportionality test laid out in Article 5(3) of the Directive. ${ }^{132}$ The proportionality test shall ensure that the disclosure of documents is reasonably limited. National courts must inter alia take into account the degree to which the claims is supported by available facts and evidence justifying the request. They must also weigh the scope and cost of disclosure, especially regarding non-specific searches for information (so-called fishing expeditions). Finally, judges must consider whether or not the evidence contains confidential information and the arrangements for protecting such confidential information. ${ }^{133}$

The Directive severely limits disclosure of material in the files of the competition authority according to Articles 6 and 7. Article 6 devises a more restrictive proportionality test for evidence held by the competition authority. The national courts must consider whether the access request has been specifically formulated with regards to the nature, object or content of the documents submitted to a competition authority, Article 6(4)(a). It must also factor in whether the access seeking party is claiming damages before a national court, Article 6(4)(b). ${ }^{134}$ Finally, the test requires that the need to safeguard the effectiveness of public enforcement is taken into account, Article 6(4)(b).

Article 6 of the Damages Directive blacklists certain categories of documents from disclosure. It temporarily precludes access to information that was specifically prepared for the proceedings of a competition authority (Article 6(5)(a)), information the competition authority has drawn up and sent to the parties in the course of the proceedings (Article $6(5)((b))$, and withdrawn settlement submissions. It is interesting to note that these categories are rather wide and are likely to incorporate most documents in the file of the competition authority that are relevant for claimants. These categories also differ from the categories the European Commission had defined for access requests under the Transparency Regulation. ${ }^{135}$ The temporary protection is lifted when the competition authority's investigation is terminated with a decision or otherwise, apparently irrespective of pending appeals. ${ }^{136}$ Once the temporary ban on disclosure is lifted, access seeking parties have to satisfy the strict proportionality test of Article 6(4)(a). Settlement submissions and leniency information enjoy absolute protection and are permanently excluded from disclosure. ${ }^{137}$ The Directive does not specify whether this level of protection applies to successful leniency applications only. Article 7 extends the protection to authority documents that are in the hands of

\footnotetext{
${ }^{131}$ Article 5(1) Damages Directive.

${ }^{132}$ Article 5 Damages Directive.

${ }^{133}$ Article 5(3)(c) Damages Directive.

${ }^{134}$ Article 6(4)(b) Damages Directive.

${ }^{135}$ See subsection II above.

${ }^{136}$ Recital 25 Damages Directive.

${ }^{137}$ Article 6(6) Damages Directive.
} 
third parties. It declares documents inadmissible in actions for damages that were gained from the competition authority through access to file requests.

The changes outlined above are likely to raise the bar for future follow-on claimants to access information. Articles 6 and 7 limit the scope of access request due to the blacklists and the strict proportionality requirements. The Directive creates a three tier test for the disclosure of authority documents in follow-on damages litigation: The courts will check the permanent blacklist first. Leniency documents and (successful) settlement submissions are not to be revealed. If the access seeking party is interested in, for example, the responses to the statements of objections, the court will move on to the second stage, checking the temporary blacklist. If the investigation has been closed or the documents requested are not banned from disclosure, the court will finally apply the specific proportionality test for confidential information.

[Insert Table 2 about here]

The rules of the Damages Directive are not without problems, especially with regards to the categories arranged in Table 2. Most categories of documents will benefit from, at least, temporary protection like, for example, the material that belongs to groups (2), (3) and (1b) in Table 2. The weakest protection is afforded to internal documents. Neither do internal documents fall under Article 6(5)(a) - information that was prepared for the competition authority - nor do they fall within the remit of Article 6(5)(b) - information the competition authority has drawn up and sent to the parties. Internal documents are normally drawn up by the competition authority but they are not sent to the parties. Recital 25 of the Damages Directive explains that the statements of objections should be protected while the investigation is ongoing but there seems to be an unintended gap for documents the Commission has drawn up but not sent to the parties. The lack of temporary protection is probably a mistake as these documents could potentially reveal strategies of the competition authorities. A careful reading of Article 4(3), stressing the special protection of internal documents, implies that this is an unintended gap. It seems reasonable to disclose internal records only after an investigation has been concluded or, in the case of important strategic documents, to keep them permanently under tight wraps.

I have argued above that the documents held by the competition authority should be classified differently, based on whether the submission was voluntary, mandatory or in exercise of the right to defence. ${ }^{138}$ The Damages Directive follows the CJEU's approach and does not blacklist material that has been obtained through dawn raids and other compulsory process. The temporary protection of documents, at least until the investigation has been concluded, is similar to the practice that is followed in the national courts with regards to, for example, responses to the statement of objections and information requests. The temporary exclusion of material from disclosure is sensible to avoid interferences between private and public cases. It should be noted that withdrawn settlement submissions are only temporarily protected. This could pose some risks for companies that initially begin settlement negotiations but then decide not to settle. Firms that have dropped

\footnotetext{
${ }^{138}$ See section II above.
} 
out of the settlement procedure would risk an increased exposure to damages litigation as their settlement documents are no longer protected once the investigation has been concluded. If it holds true that companies fear the risk of damages claims, as the Commission has repeatedly stated, this rule would press firms to come to an amicable conclusion in order to avoid the revelation of incriminating material and, thus, potential damages actions.

The strict protection of leniency documents in Article 6(6) of the Damages Directive may also breach the weighing principle established in Pfleiderer and Donau Chemie. ${ }^{139}$ The CJEU rejected any strict rule either in favour or against disclosure. The permanent blacklisting of leniency and settlement documents seems to conflict with the case by case approach adopted by the CJEU and the national courts. ${ }^{140}$ The CJEU stressed "[t]hat weighing-up is necessary because, in competition law in particular, any rule that is rigid, either by providing for absolute refusal to grant access to the documents in question or for granting access to those documents as matter of course, is liable to undermine the effective application of, inter alia, Article 101 TFEU and the rights that provision confers on individuals. ${ }^{\prime 141}$ It remains to be seen whether the Court is willing to acquiesce in the restrictions imposed by the Directive and the resulting interference with judicial discretion. In Donau Chemie, the CJEU rejected the rigid Austrian rule as incompatible with the principle of effectiveness and the right to redress. The Court held that the national law must not prevent the weighing and reduce the judge's discretion to zero. The blacklist in Article 6(6) of the Directive resembles this Austrian rule as it is strict and does not provide discretion for the judge. It effectively prevents the disclosure of leniency documents.

Other material that falls outside the first two columns in Table $\mathbf{2}$ should be accessible in civil proceedings. This will mainly apply to pre-existing documents. However, the Commission encourages the courts not to order the disclosure of information that has been supplied to the competition authority even if it relates to pre-existing information. If firms were forced to release those documents it could reveal the strategy of the competition authority and diminish incentives for the firms to cooperate. The Commission considers broad disclosure requests aiming at these materials disproportionate. In its recent Google decision the High Court did not share the Commission's assessment. ${ }^{142}$ It preliminarily limited discovery to the pre-existing documents Google had gathered for the Commission's investigation. It argued that limiting discovery to these documents would be easier and less resource-intensive than wide standard discovery. ${ }^{143}$

It is too early to tell how the Damages Directive will be implemented in the Member States, but the framework establishes tougher rules for access to documents that are or were held by a competition authority like, for example, leniency documents, settlement submissions or responses to statements of objections. This is likely to reduce the scope of disclosure in follow-on actions brought before the national courts. Few government documents would be available unless the investigation has been closed. It should be noted that the temporary protection does not include potential appeal proceedings. This could speed up proceedings. While the blacklist undeniably creates more legal certainty, it also limits the disclosure of documents in follow-on damages actions. In the next section

\footnotetext{
139 Pfleiderer (n 7); Donau Chemie (n 7).

${ }^{140}$ See section III.1.

${ }^{141}$ Donau Chemie (n 7), para 30.

142 Infederation Ltd v Google Inc (n 118).

${ }^{143}$ Infederation Ltd v Google Inc (n 118).
} 
I will show that the stricter rules, applying only to follow-on actions, document a change in private antitrust enforcement policy.

\section{Policy change in the EU}

Section II and III have demonstrated that access to documents of the competition authority is restricted in follow-in claims, especially with regards to leniency material and other confidential information. The CJEU has heightened the standards for access under the Transparency Regulation, creating a high barrier for future disclosure requests. The Damages Directive also imposes stricter requirements for access to documents in the national courts. Consequently, claimants will face delays when requesting documents in private damages actions, or they will be unable to obtain certain types of information. This issues discussed above relate to access to information but they stand for a broader change of policy, and their implications go beyond the confidentiality problems. This section shows that the courts and policy makers have adopted a more nuanced approach with regards to private antitrust enforcement.

Initially, the CJEU and the European Commission promoted private damages actions to enforce the EU and national competition law rules. The CJEU established an EU right to claim damages for the infringement of EU competition law in the Courage decision and maintained this principle in Manfredi. ${ }^{144}$ Every individual should be able to claim compensation for loss caused by the breach of EU competition rules in the courts of the Member States. The European Commission was particularly active in promoting (follow-on) damages actions as evidenced by the Commission's Green and White papers on damages actions. ${ }^{145}$ This policy pursued the aim of compensation, i.e. ensuring that victims of cartels are being made whole. It argued that every individual should have access to effective remedies securing compensation in competition law cases.

This policy was not without its flaws and based on some questionable assumptions. The Commission's policy consultations emphasised the EU right to damages, but they failed to take into account that damages are only one remedy that is available in civil litigation. Litigation data and anecdotal evidence suggests that claimants make use of other remedies too. ${ }^{146}$ Claimants in the Member States have sought primarily injunctions and invoked nullity against offenders. These remedies do not serve the aim of compensation but are nevertheless useful in stand-alone claims to prevent, for example, anticompetitive exclusionary conduct. ${ }^{147}$ While it is true that non-damages remedies are recognised on the national level and, thus, probably outside the policy-making power of the Commission, the same argument could be raised against the damages actions reform. Arguably, many damages actions are based on national competition rules but they will also benefit from the new framework for EU damages actions. Apart from the missed opportunity to create a

\footnotetext{
${ }^{144}$ Courage (n 77); Manfredi (n 77).

${ }^{145}$ White Paper ( $\left.\mathrm{n} 10\right)$; Green Paper (n 10). See the objectives in para 1.3 of the Green Paper.

${ }^{146}$ Sebastian Peyer, "Private Antitrust Litigation in Germany from 2005 to 2007: Empirical Evidence" (2012) 8 Journal of Competition Law and Economics 331-359. See generally for litigation patterns Rodger (n 2).

${ }^{147}$ See, for example, the injunction granted by the High Court of Justice in Purple Parking Ltd $v$ Heathrow Airport Ltd [2011] EWHC 987.
} 
coherent framework, the focus on damages actions has led to, what the Commission phrased as, the coordination problem. ${ }^{148}$ Antitrust damages actions, especially against cartels, are often follow-on cases, i.e. cases that are brought after the competition authority has unearthed potential evidence about the wrongdoing. ${ }^{149}$ Follow-on actions increase the fine that is imposed on culpable firms but do not increase the detection rate as they normally rely on known infringements. ${ }^{150}$ On the other hand, follow-on actions create multiple issues regarding access to information that is in the files of competition authorities. The framework for access to documents appears to favour stand-alone cases rather than follow-on claims, implicitly acknowledging the coordination problem. The disclosure restrictions make it challenging for follow-on claimants to obtain evidence from competition authorities in the courts but, at the same time, eases the access regime for evidence that does not relate to government investigations.

This change has not been made explicit but it can be documented with recent decisions and the Damages Directive. The courts and the Commission have refined the right for individual to seek redress for competition law breaches. The Manfredi and Courage doctrine still holds that every individual should be able to sue for damages in the courts of the Member States but the degree to which this right to damages is facilitated depends on whether this is a follow-on or stand-alone damages claim. ${ }^{151}$ The Damages Directive clearly facilitates stand-alone actions with disclosure rules in civil litigation - a new concept in many Member States. ${ }^{152}$ For follow-on actions, the provisions of the Damages Directive make it more difficult to access (cartel-related) information. The tests for access under the Transparency Regulation and in the national courts have also been aligned, reducing the opportunities for claimants to access information. Table $\mathbf{3}$ shows that the crucial elements of both access tests are rather similar. One could argue that access to information through national disclosure rules is less onerous because it judges have more discretion, but the very specific proportionality test laid out in the Damages Directives sets high standards for future access requests in the Member State courts.

[Insert Table 3 about here]

The nuanced and probably more restrictive private enforcement policy is likely to frustrate victims of, for example, cartels. However, the justification for rules that support follow-on damages actions is weak. Follow-on actions contribute to deterrence of anticompetitive conduct as they increase the fine companies face when breaching the law. ${ }^{153}$ It may also be regarded as a tool to compensate for public law enforcement deficits, especially since public fines are said to be below the optimal

\footnotetext{
${ }^{148}$ Recital 6 of the Damages Directive.

149 Peyer ( $n$ 146); Rodger ( $n$ 2), page 111. Rodger finds that very few follow-on actions are being brought in the EU. However, most of the stand-alone claims are not primarily damages actions. For cartels it still holds true that most damages actions are follow-on actions.

${ }^{150}$ For a different view on private damages actions see Robert $\mathrm{H}$ Lande and Joshua P Davis, 'Benefits From

Private Antitrust Enforcement: An Analysis of Forty Cases' (2008) 42 U.S.F.L.Rev. 879-918.

${ }^{151}$ See, for instance, recitals 3 and 4 of the Damages Directive; EnBW (n 7), para 104.

${ }^{152}$ Article 5 Damages Directive.

153 The CJEU recognises the deterrence effect in Donau Chemie (n 7), para 23.
} 
deterrence threshold. ${ }^{154}$ However, private enforcement is a rather uncertain and ineffective means to augment the fines imposed on companies. Instead, competition authorities should revise their fining guidelines and set fines at the appropriate deterrence level. Private enforcement is better suited to pick up smaller infringements and detect violations that the competition authorities cannot deal with or may not be aware of. The compensation objective can arguably be achieved with redress schemes sanctioned by the competition authorities. The true value of private enforcement lies in the increase of the rate of detection. Stand-alone actions increase the rate of detection, and claimants do not need to access government files. The stricter approach to access to information will, to a certain extent, discourage follow-on actions and, consequently, correct a flawed antitrust policy that was likely to raise litigation costs without adding much to the effective enforcement of competition law. This does not mean that compensation is not a valid goal of private enforcement but it means that the private antitrust policy in the EU had until recently paid too much attention to the compensatory objective.

\section{Conclusions}

Access to evidence held by the competition authorities is crucial in follow-on damages litigation. This article has shown that the two major routes for direct access to information held by the competition authority - access under the Transparency Directive and disclosure in national courts - create significant hurdles for access-seeking parties. The two tests have converged to a substantial degree. They place confidential material, especially leniency documents, legally or factually out of the claimant's reach. The restrictive approach towards disclosure will affect follow-on damages claims, especially against cartels. These limitations of private actions stand for an overdue change of EU damages actions policy. A more nuanced approach to private enforcement may sacrifice some private follow-on actions in favour of effective public enforcement. It must be stressed that this does not discourage the bringing of stand-alone claims. The change is for the better but more honesty in the policy-making process would reduce misunderstandings and lower the expectations regarding access to information and, consequently, compensation. The European Commission claims that the Damages Directive will remove "[...] practical difficulties which victims frequently face when they try to receive a fair compensation [...]"155 when, at the same time, it imposes restrictions on follow-on claims.

\footnotetext{
${ }^{154}$ Emmanuel Combe and Constance Monnier, "Fines against Hardcore Cartels in Europe: The Myth of Overenforcement" (2011) 56(2) Antitrust Bulletin 235-275.

${ }^{155}$ European Commission, "Antitrust: Commission proposes legislation to facilitate damages claims by victims of antitrust violations" (IP/13/525) Press Release of 11 June 2013.
} 
Appendix

Table 1

Table 1 - Commission's classification of documents in EnBW and protection rules under Article 4 of the Transparency Regulation

\begin{tabular}{|l|l|l|l|}
\hline Classification & \multicolumn{3}{|c|}{ Presumption of protection } \\
\hline & $\begin{array}{l}\text { Commercial interest } \\
\text { (Art 4(2), } \text { 1 }^{\text {st }} \text { indent) }\end{array}$ & $\begin{array}{l}\text { Purpose of inspections } \\
\text { (Art 4(2), 3 } 3^{\text {rd } \text { indent) }}\end{array}$ & $\begin{array}{l}\text { Internal } \\
\text { use/decision-making } \\
\text { process (Art 4(3)) }\end{array}$ \\
\hline Leniency documents (1) & Yes & Yes & No \\
\hline $\begin{array}{l}\text { Requests for information } \\
\text { (2) }\end{array}$ & Yes & Yes & No \\
\hline $\begin{array}{l}\text { Documents obtained } \\
\text { during inspection (3) }\end{array}$ & Yes & Yes & No \\
\hline SO and replies (4) & Yes & Yes & No \\
\hline Internal documents (5) & & & Yes \\
\hline -relating to facts (5a) & No & Yes & No \\
\hline $\begin{array}{l}\text {-Procedural documents } \\
\text { (5b) }\end{array}$ & No & Yes & \\
\hline
\end{tabular}


Table 2

Table 2 Document classification under the Transparency Regulation and protection under the Damages Directive

\begin{tabular}{|c|c|c|c|c|}
\hline \multirow{2}{*}{$\begin{array}{l}\text { Classification from } \\
E n B W\end{array}$} & \multirow{2}{*}{$\begin{array}{l}\text { Absolute } \\
\text { Protection }\end{array}$} & \multicolumn{2}{|c|}{ Temporary protection if } & \multirow{2}{*}{$\begin{array}{l}\quad \begin{array}{l}\text { Weighing } \\
\text { process }\end{array} \\
\text { Specific } \\
\text { proportionality } \\
\text { test applies }\end{array}$} \\
\hline & & $\begin{array}{l}\text { Specifically prepared } \\
\text { for proceedings by } \\
\text { parties }\end{array}$ & $\begin{array}{l}\text { Drawn up by } \\
\text { authority and } \\
\text { sent to parties }\end{array}$ & \\
\hline $\begin{array}{l}\text { Leniency documents } \\
\text { (1) }\end{array}$ & Yes & Yes & No & No \\
\hline $\begin{array}{l}\text { Settlement } \\
\text { submissions (1a) }\end{array}$ & Yes & Yes & No & No \\
\hline $\begin{array}{l}\text { Withdrawn } \\
\text { settlement } \\
\text { submissions (1b) }\end{array}$ & No & Yes & No & No \\
\hline $\begin{array}{lr}\text { Requests } & \text { for } \\
\text { information } & \text { and } \\
\text { replies (2) } & \\
\end{array}$ & No & Yes & Yes & No \\
\hline $\begin{array}{l}\text { Documents obtained } \\
\text { during inspection (3) }\end{array}$ & No & No & No & Yes \\
\hline SO and replies (4) & No & Yes & Yes & No \\
\hline $\begin{array}{l}\text { Internal documents } \\
\text { (5) }\end{array}$ & No & No & No & Yes \\
\hline -relating to facts (5a) & No & No & No & Yes \\
\hline $\begin{array}{l}\text {-Procedural } \\
\text { documents (5b) }\end{array}$ & No & No & No & Yes \\
\hline
\end{tabular}

Table 3

Table 3 Comparing access standards

\begin{tabular}{|l|l|l|}
\hline & Transparency Regulation & $\begin{array}{l}\text { Pfleiderer \& Damages } \\
\text { Directive }\end{array}$ \\
\hline Period of absolute protection & Appeal period & Investigation period \\
\hline Protection of categories & Yes & Yes \\
\hline Presumption of protection & Yes & Yes (blacklist for some files) \\
\hline Width of access & Individual documents & Individual document \\
\hline Burden of proof/demonstration & Applicant & Applicant \\
\hline Case by case approach & Yes & Partly \\
\hline
\end{tabular}

